\title{
Subjugation of Saga Story In Torajan's Oral Literature
}

\author{
Amriani $\mathrm{H}^{1}$, Andi Indah Yulianti ${ }^{2}$, Murmahyati ${ }^{3}$ \\ \{amrianihappe25@gmail.com\} \\ Balai Bahasa Sulawesi Selatan, Jl. Sultan Alauddin KM 7 Talasalapang \\ Makassar, Indonesia
}

\begin{abstract}
This paper aims at describing subjugation of saga story in oral literature. Saga story is a fairy tale that illustrates and reveals someone's bravery and heroism story that is connected with reality. The analysis of this paper focuses on the subjugation of society through the story and investigates the values illustrated in the story that can strengthen the social institution in society. Subjugation itself is an act of defeating someone and gaining control over someone or something. This paper uses Ruth Finnegan's approach on oral literature regarding its function, explaining that one of the functions of oral literature is to strengthen the current power of the structure of society rather than undermining it. The process of subjugation makes the power of institution become stronger because the inherited values support it. The result shows that there are several values that tends to preserve therefore the subjugation of society does exist through the inheritance of the story from generation to generation.
\end{abstract}

Keywords: Subjugation, oral literature and society.

\section{Introduction}

Oral literature is a literature describing the expressions of society based on the culture that is spread from mouth to mouth, Danandjaya [1] the spread of oral literature in society is applied in order to transform the values and norms of what people believe in it as a truth, and those must be inherited for the next generation. Oral literature is categorized as traditional literature coming from traditional era, containing a strong relationship between literature and the society who come from a place that becomes the origin of the literature. Rosidi [2] The oral literatures discussed in this paper are folklore, oral poem, expression and idiom in society. The preservation of oral tradition needs to be applied because the contents of poem, song, idiom and proverb talk about experience, condition or nowadays' occurrence, moral message that can be taken the advantages which represent the deepest feeling related to them [3]

The existence of oral literature in a community has certain purposes. Then, its purposes are called as the function of oral literature. According to Finnegan, the function of oral literature is not based on the text or the permanent characteristics in the oral literature, but it has a strong relationship with the environment where it is uttered. Finnegan [4] the function of oral literature is illustrated by Finnegan as the purpose and the effect of why it is created [4] 
Dealing with the function of oral literature, Finnegan stated that oral poetry can be used to reconcile, divide, conserve, cajole, entrance, scandalise, attack, soothe and other things [4]. The explanation above shows that oral poetry has several functions; those are as a reconciliation tool, a literature that shows the difference between certain societies with the other societies, preserves the tradition, persuades people to do something, introduces the new things, gives warning or scare people by giving a real illustration toward something, attacks or complains something and as a tool to remove the burden and pain and to strengthen the current power of the structure of society rather than undermining it.

In achieving the purpose of oral literature as the tool for strengthening the existing social structure therefore it needs to input the values or the factors that can facilitate its structure. By transforming the values of oral literature continuously, it increases what people believe that its content is a truth, then, it is called as the process of subjugation. Subjugation itself is a concept related to the subordinate that is interpreted in postcolonial studies. Subjugation uses the concept of post colonialism. Its discussion is not just about historical sense, but it also talks about the social relationship where individual, group and culture are forced into subjugated position by another individual, group and culture which have power.

Bokay in Gera [5], Sometimes people do not consider the process of subjugation that is occurred in society. subjugation and its accompanying vices that seek to acquire power and fan the ego continue to morph and exist in guises [6] they accept the values of the story and they are unconsciously subjugated by listening to the story and then inherit the same story to the next generations. The result shows that the social structure that is strengthened by the story is unconsciously getting stronger.

This paper analyses the folklore in Torajan's oral literature, saga story, as fairy tales that illustrate or describe someone's bravery and heroism which are connected with reality. Its character is someone who has strength, divine power and role that is related to historical event. Bachri [7] Saga story are chosen to investigate the illustration of the character that is categorized as a hero in Torajan's oral literature by analysing the values shown by the hero in the story therefore it will find the social structure that will developed by the society supporting that oral literature.

\section{Research Methods}

This paper uses document analysis by collecting the data in the book with the title "Struktur Sastra Lisan Toraja". The saga story in that book is used as the primary data of this paper. The data is identified by classifying the relevant parts with this paper as the part of the story describing the character of the hero. And then, the data is interpreted by pointing to the literature that related to the topic discussed in this paper. The result of this paper uses descriptive.

\section{Results and Discussion}

\subsection{Concept of Saga Story Heroism in Torajan's Oral Literature}

In Torajan's oral literature, the character of a hero is illustrated through the moral values showing the good side and the bravery of the character, that it is believed as a truth by people supporting that oral literature. The values found in the story are: 


\section{Forgiving Woman}

In the story of Bunga Alluq and Dolitau, the character of a hero is illustrated through the figure of Bunga Alluq. The character of Bunga Alluq is illustrated as a forgiving woman. In the story, Bunga Alluq forgives and accepts her huband's mistake who has cheated and got married with another woman. Forgiving occurs when someone sincerely accepts the reality to forget the hurting mistake or sin happening in the past. After forgiving, the mistake will be forgotten and not talk about it again to avoid the anger and hatred that can hurt other people and yourself. According to Mc Cullogh [8], forgiving is a kind of motivation to change someone for not doing revenge, reducing the feeling of hatred toward the hurting side and also increasing the motivation for conciliating the relationship with the hurting side.

The vacuity of Bunga Alluq in forgiving her husband can be seen through the excerpt below:

\section{Bahasa Indonesia}

"Dolitau sudah selesai makan. Bunga Alluq melepaskan tenunannya lalu pergi bercakapcakap dengan Dolitau, "masih enakkah daging dendeng yang sudah tersimpan lama itu?' Dolitau menjawab, " mana mungkin tidak enak kalau hati babi dan hati kerbau sebab bagian itulah yang paling enak kalau dikeringkan atau didendeng." Bunga Alluq berkata, "tidak mungkin hati babi dan hati kerbau, dari mana pula saya bisa mendapatkannya. Dendeng yang enak kau makan itu adalah hati istrimu yang bernama Katiliaq.” Setelah Dolitau mendengar kata-kata Bunga Alluqitu, ia langsung pingsan karena hal itu sama sekali di luar dugaannya. Waktu itu dolitau merasa bersalah lalu ia mengakui perbuatannya serta memohon ampun kepada Bunga Alluq. Mulai hari itu kembalilah ia damai dan berkasih-kasihan hidup bahagia di dalam rumah tangganya karena Dolitau tidak mau pergi kawin lagi” [9]

\section{English version}

"Dolitau had already eaten. Bunga Alluq put her hands away from her fabric and went out for having a talk with Dolitau, "is this stale dendeng still delicious?". Dolitau answered "How come the pig's and buffalo's offal are not delicious while both are the most delicious part to dry and cook to be dendeng". Bunga Alluq said "it is impossible to find the offal of pig and buffalo in this place, the dendeng that you have eaten is the meat of your wife, Katiliaq". After listening to Bunga Alluq's explanation, he was getting collapsed because it was not like what he thought before. At that time, Dolitau felt so mistaken and he admitted what he had done and asked apologize to Bunga Alluq. After that day, he lived in peace and happily in his family because Dolitau would not get married again."

The excerpt above illustrates the regret of Dolitau for making his wife disappointed and heartbreaking because he has got married again. The wife (Bunga Alluq) even kills the second wife of her husband to defend her position. Although the disappointment felt by Bunga Alluq on what has been done by Dolitau, but she keeps forgiving her husband. Dolitau feels so mistaken and then he asks apologize to his wife and promises for not repeating it.

At the story above, Bunga Alluq is as a hero who forgives her husband who has hurt her. Forgiving other people is difficult to do because it needs to change the negative feeling toward somebody into positive feeling. In fact, it cannot be done fast and needs a long process so that the character of Bunga Alluq is categorized as a heroic character. It is illustrated through the excerpt below: 


\section{Bahasa Indonesia}

"Tidak lama kemudian, pada suatu hari Bunga Alluq melihat Dolitau memakai baju hitam lalu ia bertanya, " mengapa engkau memakai baju hitam Dolitau? Apakah ada sesutau?” Ada seseorang tetangga yang meninggal dunia dan baru selesai diadakan pestanya. Setelah bercakap-cakap demikian, Bunga Alluq berkata kepada anaknya yang berada di atas rumah, katanya "masakkanlah ayahmu karena ia capek baru datang!"[9]

\section{English version}

"No longer than, one day, Bunga Alluq found Dolitau while wearing black clothes. And then, she asked "why do you wear black clothes? Is there anything wrong?" One of their neighbour had passed away and the ceremony had just been held. After talking about that, Bunga Alluq told her sons staying at the uppers side of their house. She said "cook some foods for your father who has just come" [8]

Without feeling mistaken, Dolitau goes home to his first wife's house after attending the funeral ceremony of his second wife (Katiliaq). Bunga Alluq who has known the real tragedy does not try to insult her husband, she even asks her son to serve food for her husband. The loyalty of Bunga Alluq as a wife is illustrated through the excerpt above, although Bunga Alluq actually feels disappointed about the betrayal that has been done by her husband, but she still welcomes her husband while going back home. Bunga Alluq even does not try to pry deeper about what has been attended by her husband even though she knows that it is the funeral ceremony of Katiliaq. The forgiveness given by Bunga Alluq to her husband is done to make Dolitau realize his mistake and not to repeat it again. She believes that a good wife is the one who can forgive the mistakes of her husband.

The forgiveness used to be given by the victims because they are insisted to fulfil the social role in society (Zechmeister and Romero) [10]. Bunga Alluq who forgives her husband because of his deed is a kind of forgiveness that is used to fulfil the social role as a wife. In a patriarchal society, a wife used to be insisted to forgive her husband's mistake who was assumed for having superiority rather than a wife, That assumption has been conventionally considered by society especially in case of affair like what Dolitau did. A husband who cheats was considered as a normal attitude therefore it is also something ordinary if a wife forgives her husband who has betrayed her. Forgiveness is also often given by wives because they hope their husbands will correct their mistakes and their household will be better [11]

The condition of patriarchal society which give specialty toward man makes this situation becomes mainstream and acceptable. A woman who cheats with the husband of another girl is marked with a special nickname, that is pelakor (the usurper of another woman's husband) and this term becomes very popular in society. The same thing does not prevail with man who cheats another woman although it also has a special nickname mentioned in social media, that pebinor (the usurper of another man's wife) but it is not popular in society.

Pebinor and Pelakor have different point of view, the woman who is marked as pelakor will always be marked negative by society and will be stayed away by society. However, it is different the man who is marked as pebinor is still accepted and easy to forget by society. This kind of situation expressed by French feminist writer Simone de Beauvoir while explaining the hierarchy of sexes: "This has always been a man's world" [12]. Even though, it is an ordinary thing while a wife forgives her cheating husband, but it is still a kind of difficult to do. Therefore, the woman who can do it is considered a great woman. 


\begin{abstract}
A Brave Woman
In the story of Bunga Alluq and Dolitau, the character of Bunga Alluq is illustrated as a hero who struggles to defend the integrity of her family. Bunga Alluq can face the reality about the affair of her husband. A husband who cheats is considered as normal thing and it is even a big mistake when a woman receives the man's love who has been married. It is shown at the excerpt below:
\end{abstract}

\title{
Bahasa Indonesia
}

"Kira-kira menjelang subuh bangunlah Bunga Alluq mengambil tungku dan membuangnya ke atas plafon. Seorang pun tidak ada yang menegurnya, ini berati orang sudah tidur nyenyak karena semuanya letih setelah bekerja pada siang harinya. Bunga Alluq mulai menyiram dapur dan memadamkan lampu pelita. Setelah ia melaksanakan semuanya itu, pergilah ia ke kamar rumah yang paling selatan mencari Katilaq dan membunuhnya. Bunga Alluq berhasil melaksanakan niatnya membunuh Katilaq lalu membelah perutnya dan mengambil hatinya." [9]

\section{English Version}

"Before coming to the dawn, Bunga Alluq woke up to take a fireplace and threw it into the above side of the roof. No one admonished her which means that all people were sleeping profoundly because they had worked hard at the afternoon. Bunga Alluq started watering and turned off the oil lamp. After doing that all, she went to the bedroom at the southernmost of her house to look for Katiliaq and killed her. Bunga Alluq had successfully killed Katilaq and cleaved her stomach and took her heart."[8]

The excerpt above illustrates the struggle what has been done by Bunga Alluq to keep the integrity of her family by killing the woman who has cheated with her husband. This phenomenon can provoke an assumption that affair occurs because the mistake of a woman without considering that the man also has the same role in a relationship. Actually, a man and a woman also have the same role in an affair but the promulgation of society toward an affair that is done by a man is bigger rather than a woman doing it.

The construction of the heroic character that is described in the story illustrates a brave woman who struggles to keep the integrity of he family. One of the characters that illustrated in the story of Bunga Alluq is a brave woman who kills her husband's another woman. What has been done by Bunga Alluq is illustrated as an effort to protect her family from the disturbance from another woman.

One of the bias point of views is a woman is always categorized as a fainthearted and a sensitive human. Nurhayati [13] stated that based on a research, boys and girls have a brave character and love having adventure when they are still a kid. However, when they have grown up, the construction about a brave boy and a fainthearted girl is continuously inherited to them verbally or through an action. One of the examples is a girl used to be feared while wanting to climb a tree or doing a man's job or activity. It even can make a girl tend to be a coward. In otherwise, boys will be bullied while feeling afraid and hesitant to do something therefore they will grow up to be brave and a man who never feels afraid of new challenges.

Bunga Alluq's bravery in killing Katiliaq is categorized as a brave and a heroic decision because that kind of action used to be done by a man. However, Bunga Alluq who was disturbed with the existence of Katiliaq who is considered as a disturber in her family is brave to do that murder. Based on the norm in society, that deed is categorized as an immoral character and breaks the rule. However, in this story, Bunga Alluq is considered as a good deed because she has been brave to give a punishment to her husband by killing his second wife. 
The heroism construction that is shown through a brave character of Bunga Alluq gives an illustration that a double standard for a woman, that is a woman is considered for being brave if her action is done to defend a man otherwise a brave deed that is done to show their existence used to be underestimated. As the example, a woman who chooses for not getting married and having carrier will viewed negative in the eyes of society with several nicknames, such as an old virgin. Actually, the choice chosen by that woman is a kind of brave choice because they can fight against the establishment of social institution that has been believed by many people as an absolute truth.

\subsection{Functional Subjugation in Saga Storiy in Torajan's Oral Literature}

The saga story in Torajan's oral literature illustrates the heroic figure inherited from generation to generation. Based on the example above, the character of Bunga Alluq has been described as the character of a hero who has forgiving character as she forgives the mistake of her husband and also a brave character for taking an action to kill the woman becoming her husband's mistress.

The illustration of the character of a woman in the story is not described without purposes but it is described by intending to give a special message that delivered to people to get those characters in their life. The function of oral literature is as a facility to strengthen the social institution can be found through the illustration of the figure of a woman in the story of Bunga Alluq and Dolitau. Bunga Alluq is a woman who is illustrated for having a forgiving and brave character. Through this explicit illustration, there is an ideology that intend to be strengthened in society.

Through the story of Bunga Alluq and Dolitau, the patriarchal ideology is strengthened by constructing the heroic woman as a woman who can forgive her husband's mistake, especially in case of an affair. It is because an affair is categorized as an ordinary thing that is done by a man because in the view of gender, a man is constructed for having a masculine character who loves adventure and new challenges. The illustration of a heroic woman in the story views a woman must be able to forgive that mistake is categorized as a normal thing. The illustration of the woman as a forgiving character is a subjugation that is done to strengthen the patriarchal ideology. Through this story, a woman is constructed to be submissive to a man and accept the affair of her husband.

Even though Bunga Alluq is illustrated as a forgiving woman, she is also a brave woman. It is shown by her bravery in killing her husband's mistress. However, Bunga Alluq's decision for killing is just to defend the integrity of her family. In woman's perspective, a marriage is an important thing, and its integrity must be protected no matter what it takes. The illustration shows that woman is subjugated to give an understanding that in an affair, the second wife tends to have a bigger role in doing mistake.

\section{Conclusion}

Through saga story in Torajan's oral literature, it is found that there is a process of subjugation as the preservation of the values illustrating a heroic woman who wants to live happily with her husband that is by becoming a forgiving and a brave woman. This values preservation is done continuously by inheriting the story from generation to generation. Its purpose is to strengthen the social institution of the society supporting that oral literature. The society supporting that oral literature are unconsciously subjugated by believing its values as a 
truth and they also do not consider that there is certain ideology which tends to be strengthened in the story, that is patriarchy.

\section{References}

[1] J. Danandjaja, Folklor Indonesia: Ilmu Gosip, Dongeng dan lain-lain. Jakarta: Gartifipers, 1997.

[2] A. Rosidi, Sastra dan budaya kedaerahan dalam keindonesiaan. Jakarta: Pustaka Jaya, 1995.

[3] J. Vansina, Tradisi Lisan Sebagai Sejarah. Yogyakarta: Ombak, 2014.

[4] R. Finnegan, Oral poetry, its nature, significance and social context. Cambridge: Cambrige Unversity Press, 1977.

[5] J. Gera, Structure of Subjugation in Dutch Literature. Great Britain: Modern Humanities Research Association, 2016.

[6] E. O. Ebekue, "Intra-Gender Subjugation among Women in Nigeria: A Study of Stephanie Okere's Dry," Creat. Artist A J. Theatr. Media Stud., vol. 11, no. 1, pp. 84--102, 2017.

[7] Bachri Bahtiar, Pengembangan Kegiatan Bercerita di taman kanak-Kanak, Teknik dan Prosedurnya. Jakarta: Depdiknas, 2005.

[8] J. . McCullough, M.E., Bellah, C.G., Kilpatrick, S.D., and Johnson, "Vengefulness: Relationship with Forgiveness, Rumination, Well-Being, and The Big Five," vol. 27, pp. 601-610, 2001.

[9] et al Sikki, Muhammad, Struktur Sastra Lisan Toraja (transkripsi dan Terjemahan). Jakarta: Pusat Pembinaan dan Pengembangan Bahasa Departemen Pendidikan dan kebudayaan., 1986.

[10] C. Zechmeister, J.S., dan Romero, "Victim and Offender Accounts of Interpersonal Conflict: Autobiographical Narratives of Forgiveness and Unforgiveness,” J. Pers. Soc. Psychol., vol. 82, no. 4, pp. 675-686, 2002.

[11] P. A. L. and S. Permata, "Forgiveness Istri pada Suami yang Pernah Berselingkuh dan Menganggur," Intuisi J. Psikol. Ilm., vol. 7, no. 1, pp. 24--27, 2015.

[12] S. de Beauvoir, second sex, fakta dan mitos, Terjemahan. Surabaya: Pustaka promethea, 2003.

[13] E. Nurhayati, Psikologi Perrmpuan dalam Berbagai perspektif. Yogyakarta: Pustaka Pelajar, 2012. 